What are the views of hospital based generalist palliative care professionals on what facilitates or hinders collaboration with in-patient specialist palliative care teams? A systematically constructed narrative synthesis

1) Janice Firn, L.M.S.W.

F7902 University Hospital - South

1500 E. Medical Center Drive, SPC 5233

Ann Arbor, Ml 48109

USA

jfirn@med.umich.edu

Affiliations:

University of Michigan Health System, Division of Geriatric and Palliative Medicine Ann Arbor, Michigan, USA

Division of Health Research, Lancaster University, Lancaster, United Kingdom

2) Nancy Preston, PhD.

International Observatory on End of Life Care

Division of Health Research

C52 Furness Building

Lancaster University

Bailrigg

Lancaster, LA1 4YG

UK

n.j.preston@lancaster.ac.uk

Affiliations:

International Observatory on End of Life Care, Faculty of Health and Medicine, Lancaster University, Lancaster, United Kingdom

3) Catherine Walshe, PhD.

International Observatory on End of Life Care

Division of Health Research

C52 Furness Building

Lancaster University

Bailrigg

Lancaster, LA1 4YG

UK

c.walshe@lancaster.ac.uk

Affiliations:

International Observatory on End of Life Care, Division of Health Research, Lancaster University, Lancaster, United Kingdom 
Firn, Preston, and Walshe

\title{
What are the views of hospital based generalist palliative care professionals on what facilitates or hinders collaboration with in-patient specialist palliative care teams? A systematically constructed narrative synthesis.
}

\begin{abstract}
Background: Hospital-based specialist palliative care services are common yet existing evidence of inpatient generalist providers' perceptions of collaborating with hospital-based specialist palliative care teams has never been systematically assessed.
\end{abstract}

Aim: To assess the existing evidence of inpatient generalist palliative care providers' perceptions of what facilitates or hinders collaboration with hospital-based specialist palliative care teams.

Design: Narrative literature synthesis with systematically constructed search.

Data sources: PsycINFO, PubMed, Web of Science, CINAHL, and ProQuest Social Services databases were searched up to December 2014. Individual journal, citation, and reference searching were also conducted. Papers with the views of generalist inpatient professional caregivers who utilised hospital-based specialist palliative care team services were included in the narrative synthesis. Hawker's criteria were used to assess the quality of the included studies.

Results: Studies included $(n=23)$ represented a variety of inpatient generalist palliative care professionals' experiences of collaborating with specialist palliative care. Effective collaboration is experienced by many generalist professionals. Five themes were identified as improving or decreasing effective collaboration: model of care (integrated vs. linear), professional onus, expertise and trust, skill building vs. deskilling, and specialist palliative care operations. Collaboration is fostered when specialist palliative care teams practice proactive communication, role negotiation, and shared problem-solving, and recognize generalists' expertise.

Conclusion: Fuller integration of specialist palliative care services, timely sharing of information, and mutual respect increases generalists' perceptions of effective collaboration. Further research is needed regarding the experiences of non-physician and non-nursing professionals as their views were either not included or not explicitly reported.

\section{Key Words [mesh headings]}

Palliative care; Integrated; Interprofessional relations; Attitude of health personnel; Communication; Referral and consultation

\section{What is already known about this topic?}

- Effective collaboration leads to better patient outcomes, improved patient satisfaction, reduced hospital length of stay, lower health care costs, and decreased delays in care provision.

- Barriers to and facilitators of collaboration between generalist and specialist palliative care professionals have been identified in both the outpatient and community settings.

\section{What this paper adds?}

- This review identifies barriers to and facilitators of collaboration between generalist and specialist palliative care professionals when integrating specialist palliative care services in the inpatient hospital setting. 
- Hospital-based generalist palliative care professionals experience similar barriers to and facilitators of collaboration as their outpatient and community setting counterparts.

- Full integration of specialist palliative care services in the hospital setting remains limited.

\section{Implications for practice, theory or policy?}

- Integration of hospital-based specialist palliative care services into patients' end of life care is increased when specialist palliative care teams communicate effectively, are open to role negotiation, are readily accessible, and share problem-solving responsibilities with and recognize the expertise of generalist palliative care providers.

- The frequency of contact between generalists and specialist palliative care teams in the inpatient setting provides increased opportunities for collaboration, enhances the frequency of communication, and aids in the development of mutual knowledge.

- The urgency of patient need in the hospital and the on-site location of the specialist palliative care team may increase the value generalists' place on the responsiveness of the specialist team, making timely responses and frequent communication even more important.

\section{Introduction}

Integration of multiprofessional specialist palliative care teams into hospitalized patients' end of life care is becoming the norm (1-5). These types of specialist palliative care teams serve a supporting role to generalist teams who have primary ownership and responsibility for the patient. In the hospital setting integrated specialist palliative care 'seeks to improve the quality of care for patients by ensuring that services are well coordinated around their needs' through effective professional collaboration (6). Effective professional collaboration achieves better patient outcomes, improves patient and provider satisfaction, reduces length of stay, lowers costs, and contributes to fewer and shorter delays in the provision of care, as well as increases staff work efficiency and lowers staff stress (7-14). Professionals' perceptions of collaboration are strongly correlated with achieving these outcomes (15-18). Studies of providers' perceptions of collaboration in the broader healthcare arena show the greatest impact on patient outcomes occurs when physicians, nurses, and social workers are satisfied with their professional relationships with one another (15). In the palliative care literature to date there has been no systematic assessment of the evidence regarding hospital-based generalists' perceptions of collaboration with integrated specialist palliative care teams. 
This paper is the first to systematically review the evidence of generalists' experiences collaborating with specialist palliative care teams in the hospital. Previous systematic reviews looking at collaboration between generalist and specialist palliative care providers have focused on the community setting (19-22). Results from these earlier reviews may not apply to a hospital-based care setting. The inpatient hospital setting differs greatly from that of the community: the acuity of patients is higher, immediacy of patient needs and response time from providers is more pressing, and providers episodically care for patients rather than follow patients for the entirety of their disease process. Specialist palliative care professionals have proposed several strategies for effective collaboration with generalist providers in the hospital related to communication, being accessible and responsive, and respecting the authority of the referring providers $(23,24)$. Evidence about generalists' perceptions of these efforts towards collaboration have been highlighted in the literature but not systematically assessed. A systematic review of the literature will provide a greater understanding of generalists' perceptions of collaborating with specialist palliative care teams and the conditions under which collaboration is facilitated or hindered.

\section{Methods}

Aim:

To identify and assess the current evidence to determine what is known about hospitalbased generalist providers' perceptions of what facilitates or hinders collaboration with inpatient multiprofessional specialist palliative care teams.

Review design:

The review follows the Guidance for Narrative Synthesis (Popay et al. 2006). Narrative synthesis is a rigorous review approach which facilitates synthesis of heterogeneous studies. The existing evidence on integrated hospital-based palliative care is diverse thus an approach that facilitates the synthesis of heterogeneous literature is needed. The Preferred Reporting Items for Systematic Reviews and Meta-Analysis (PRISMA) (25) guidelines are 
followed in the reporting of the review. The definitions of terms used in the review are in Table 1.

$<$ Insert Table 1 around here >

\section{Search Process}

\section{Database Searches}

The databases of PsycINFO, PubMed, Web of Science, CINAHL, and ProQuest Social Services Abstracts were searched for articles published from 1 January 1990 to 31 December 2014. Data about integrated palliative care produced before 1990 is scarce and may no longer be relevant as the palliative medicine field has evolved, therefore, was not included. The major palliative care journals were also hand searched: The American Journal of Hospice and Palliative Medicine; European Journal of Palliative Care; Journal of Hospice and Palliative Nursing; Journal of Pain and Symptom Management; BMC Palliative Care; Palliative Medicine; Journal of Palliative Medicine; and Journal of Social Work in End-of-Life and Palliative Care (26). Lastly, citation tracking was completed using Web of Science and the included studies' reference lists were reviewed for relevant articles. The searches were conducted in April/May 2014 and updated in December 2014.

\section{Database Search Terms}

For those databases which use MeSH headings or a thesaurus, these were employed to initiate the search. Included search terms and the Boolean operators used are in Table 2. Where the same terms did not exist, the closest substitutive terms were chosen to maintain as much consistency as possible throughout the search process. The search strategies for each database can be found in (Appendix A).

$<$ Insert Table 2 around here>

\section{Selection Criteria}

Inclusion criteria: 
- English language research studies reporting empirical data published in peer-reviewed journals.

- Studies describing the interaction, perceptions, attitudes, and experiences of hospital based generalist care providers with at least one member of the hospital specialist palliative care team when simultaneously caring for a patient, even if the topic is only a minor focus of the study.

- Studies describing generalists' perceptions of the factors that facilitate or are barriers to collaboration with the hospital based specialist palliative care team.

- Studies focusing on generalists and specialists providing care to adult patients within the acute hospital setting.

- Studies with a quality score of 20 or above on the scoring tool created by Hawker et al 2002.

\section{Exclusion criteria:}

- Grey literature, newspaper articles, editorials, non-peer-reviewed articles, theoretical papers, and publications consisting of subject matter expert opinions.

- Studies with pediatric palliative care providers or occurring in pediatric hospitals, taking place in the outpatient ambulatory care, community based palliative care, or freestanding hospice settings, and studies of obstetrics and maternity wards.

- Studies exploring intra-team interactions between specialist palliative care team members, or the interactions between specialist palliative care providers and patients and carers, or interactions between generalist palliative care providers and patients and carers, or describing only generalist palliative care.

\section{Data Extraction \& Analysis}

The search strategy was designed by JF, CW, and NP. Papers were identified and assessed by JF, decisions regarding inclusion of papers was discussed with and reviewed by CW and NP. The narrative synthesis guidelines recommended by Popay et al (27), that is (1) preliminary analysis, (2) exploration of relationships, and (3) assessment of the robustness 
Firn, Preston, and Walshe

of the synthesis, were carried out by JF and reviewed by CW and NP. Preliminary synthesis entailed extracting the descriptive characteristics of the studies in a table and generating a textual summary of the results. Thematic analysis was then used to extract the main themes. Data from the studies were extracted into a table and thematically analyzed by JF and discussed with CW and NP. The five themes developed in the results section represent the main areas of knowledge available about collaboration between hospital-based generalist and specialist palliative care providers. Identification of themes was arrived at after deliberation and discussion between JF, CW, and NP. The review was written by JF, with guidance and editing provided by CW and NP.

\section{Results}

A total of 23 articles met the inclusion criteria and were included in the synthesis (Figure 1: PRISMA flow diagram).

$<$ Insert Figure 1 somewhere around here>

\section{Assessment of Quality}

Hawker et al.'s scale was used to assess the quality of the 23 studies (28). The scale was created to assess heterogeneous studies (28). Previous palliative care related systematic literature reviews have utilized the scale $(21,22,28,29)$. The overall score for each study can be as low as 9 to as high as 36 . Scores of the 23 identified studies ranged from 25 to 36 , with a median score of 31 . All of the studies were included in the synthesis as they met the inclusion criteria of a score of 20 or higher. Overview of Studies

The publication dates of the studies ranged from 2001 to 2014 and were heterogeneous, with 12 being qualitative (30-41), six quantitative (42-47), and five mixed methods (48-51). Of the 23 studies, ten were from the UK $(30-33,36,39,42,45,46,49)$, five from the USA $(34,35,38,47,50)$, and three from Australia (37, 41, 51). New Zealand (48), France (43), and Japan (52) all had one study each. There were two multi-country studies, one which included respondents from Australia, USA, Asia, Africa, and Europe (44), the specific Asian, African, and European countries were not identified, and one which included respondents from both England and New Zealand (40). Study hospitals ranged in type from small secondary care centres to large tertiary teaching hospitals. One specialist cancer centre (36) 
Firn, Preston, and Walshe

and one acute stroke centre (39) were also included. The smallest hospital had 240 beds (47) and largest had 1300 beds (32). Hospitals were located in urban, inner city, and rural settings. Specialist palliative care team membership varied considerably (Table 3). Half of the studies did not identify the professional membership of the specialist palliative care team. Study specialist palliative care teams had been active for as little as 1 year (35) to as much as 11 years $(36,52)$. The referral models ranged from hospitals where any member of the ward team could make a referral to specialist palliative care (48), to hospitals where referrals could only be made with the approval of the attending (head) physician (50). No consistency existed in the titles or terms used to refer to the hospital-based specialist palliative care teams.

$<$ Insert table 3 around here $>$

\section{Themes}

Analysis produced the following five themes: Model of Care (Integrated vs. Linear);

Professional Onus; Expertise and Trust, Skill-Building vs. Deskilling, and Specialist Palliative Care Operations. Each study contributed to different number of themes, with some studies having multiple themes and some only two or three (Table 3). The five themes are discussed below.

Model of Care: Integrated vs. Linear

Two models of care emerged from the literature review; an 'integrated' model and a 'linear' model. Whilst formal definitions of integrated and linear care exist, the descriptions of each model used here have risen from the studies themselves and are not formal definitions. Here 'integrated care' is concurrent care between generalist and specialist palliative care providers. It consists of a multiprofessional approach to patient care, combining various health and social care specialties, services, and professionals to meet the need of the patient at different points in time throughout the course of an illness. Studies reporting a more integrated approach to care noted higher utilisation of multiprofessional specialist palliative care services, viewed palliative care as applicable throughout the disease process, 
and deemed it appropriate for use in a variety of life-limiting illnesses (i.e. not just cancer) $(33,35-38,42,43,48,51)$. 'Linear care' here views transitions to different specialties as a passing of the 'care baton.' In linear care, one type of care ends before another begins. An integrated care approach was preferred and implemented in 12 studies $(32-36,41,42,44$, 46, 49-51). Four studies consisting of Cardiology $(31,42)$ and Neurology $(39,45)$ professionals found these providers preferred and took a more linear approach to palliative care involvement. Of the seven remaining studies, three did not provide enough information to determine model of care $(30,33,52)$, three reported that integrated care is desired but not actualised into patient care $(37,41,46)$, and one reported a mixed response about which model of care was preferred (40).

Of those studies which reported generalist providers as viewing an integrated care model positively, integrated care was seen as a means to address patient and family needs whilst still fulfilling the professional's obligation to remain involved in the patient's care (35$38,42,44,50,51)$. Integrated care model providers preferred an 'unequal' partnership with specialist palliative care, one where the referring team claims the leadership role, and the specialist palliative care team answers to the leader. In the majority of studies integrated care model providers maintain the right to their autonomy in medical decision making (35-38, $42,44,50,51)$. These findings were consistent across the studies regardless of provider type (nursing, physician, etc.), country, and hospital size.

Three studies reported that several providers preferred a linear model where they are able to 'hand over' their patients' care to specialist palliative care teams after they had delivered all the interventions at their disposal $(31,39,45)$. The 'linear model' was more often associated with providers whose skills and options for patient care included a broad range of interventions, those that were most frequently mentioned were Cardiology, Neurology, Oncology, General Surgery, and Vascular Surgery $(31,34,39,41,44-46)$. In the studies these providers were more likely to express that their area of responsibility was 
being invaded when specialist palliative care became involved earlier in the illness trajectory $(33,34,36,38,40,49,50)$.

The Oncology related studies spanned a variety of settings and countries, whilst those studies reporting responses from Cardiology, Neurology, General Surgery, and Vascular Surgery were conducted in the UK, USA, and Australia only and included only one specialist centre (stroke). Findings related to generalist Oncology views may be more broadly applicable as a result. Additionally, whilst there are bound to be variations amongst groups of providers, of the five groups listed above Oncology was found to be the most polarised in their preferences for integrated versus linear care, half favouring linear and the other half favouring integrated care $(31,34,36,39,41,44,45,51)$. Oncology results were persistently polarised across countries, regardless of specialist palliative care team membership or hospital setting (i.e. specialist cancer centre vs. secondary hospital).

\section{Professional Onus}

Professional onus denotes the provider's professional responsibility towards the patient and the duration of that responsibility. Studies reported a range of results between studies as a whole and within individual studies. Several studies found that some generalist providers were concerned that involvement of the specialist palliative care team was an abdication of responsibility or a sign that they have either 'given up on' or 'failed' the patient $(29,30,34$, $35,37-40,43,44,46,48)$. A number of studies also reported the opposite finding, with many generalist providers' viewing specialist palliative care involvement as an extension of their responsibility and a way to increase the care given to the patient $(31,33,34,36,37,39,40$, $42,44,45,50,51)$. In studies where specialist palliative care involvement was perceived as an extension of their role, providers struggled less with the timing of the referral, involving specialist palliative care earlier in the disease course $(35-37,43,44,47,48,50)$. Providers who perceived specialist palliative care involvement as the end of their role in patients' care had more difficulty determining when to involve specialist palliative care, sometimes waiting until days to hours before death $(31,34,37,39,40,42,44,49,50)$. 
Also included in professional onus are the concepts of 'abdication of responsibility' and 'professional laziness'. With the integration of specialist palliative care, studies indicated generalist providers were concerned with becoming 'disinclined' to provide the patient with care which would normally be within their purview $(32,40,49)$. Generalists' worried that providers would 'take a back seat' to specialist palliative care teams, remaining on paper the patient's provider but in reality being absent $(33,40)$. Furthermore, there was a strong sense that every generalist provider should know and be competent providing 'basic' palliative care services to all of their patients $(31-34,36-40,42,44-46,49)$. These findings were consistent regardless of country, hospital size, specialist palliative care team membership, or study design. Overall, whilst generalists were reported to have concerns for abdication of responsibility, these fears were not realised. Generalist providers were able to maintain their role and responsibilities towards their patients if they desired to do so.

\section{Expertise and Trust}

The themes of expertise and trust appeared in many of the studies $(30,31,33-36,38-42,44-$ 46, 49-51). Expertise and trust were often coupled together, at times used interchangeably, making it difficult to definitively distinguish and report each as separate themes. Whilst formal definitions exist, the meanings of expertise and trust used here are derived from the studies themselves. Definitions here are limited by the conflation of terms within the original studies. Trust relates to the referring team's ability to rely on the specialist palliative care team to act as desired. Desired behaviours consist of respecting the hierarchy of decision making, particularly as it relates to treatment planning, recommended clinical direction, and goals of care, as well as communicating frequently with the all the ward staff involved in the patient's care $(33-35,37-39,45,47,48,51)$. Expertise refers to the specialist palliative care team having a strong working understanding of specific disease trajectories and available active treatment options for each disease process in order to counsel patients about choices for continuing care $(31,45,46,50,51)$. Expertise also consists of having the necessary medical, psychosocial, and spiritual skills to adequately address the needs of the patient (31, 
Firn, Preston, and Walshe

33-35, 47-49, 51). Irrespective of hospital size, disease type, country, and specialist palliative care team membership trust was increased when the specialist palliative care team was able to consistently demonstrate their expertise and referring teams became convinced of their capabilities.

Many studies reported referrers as having a high level of respect for the specialist palliative care skillset, viewing the services specialist palliative care provided as requiring extra training and experience to execute $(32-34,36,37,44)$. Generalists' perceptions of the level of skill involved in specialist care services directly impacted their willingness to refer and the types of issues they requested be addressed $(31-34,48)$. In particular, Cardiology, Neurology, Physical Rehabilitation, and Oncology providers' perceptions of specialist palliative care's disease specific expertise, or lack thereof, impacted how much they trusted specialist palliative care and directly impacted the teams' willingness to integrate care (31, $34,38,39,41,42,44-46)$. This view made it particularly difficult for these providers to trust specialist palliative care's ability to adequately discuss goals of care or make appropriate treatment related recommendations $(39,42,44-46,53)$. Conversely, several studies reported generalists' perception that specialist palliative care was at times dismissive of the ward team's expertise and role in patients' care, as exhibited by failing to include them in the plan of care, discuss recommendations, or update them on what was discussed during family meetings $(30,33,35,48,49,52)$. Areas where generalist teams were able to acknowledge their own discomfort and lack of expertise mirrored the areas for which they were more likely to integrate specialist palliative care services unrelated to country, disease type, hospital size, or specialist palliative care team membership. Trust and utilisation were fostered when both the referring team and the specialist palliative care team were able to express mutual respect and appreciation for each other's roles, expertise, and contributions to patient care outcomes, and when communication was high $(35,36,38,48,49,51,52)$. 
The attention to skill-building vs. deskilling was shared by all provider types (nurse, physician, social worker, administrators, etc.), persisted regardless of specialist palliative care team membership, country, or hospital size. Skill-building was viewed as desirable by the generalist ward staff, and was identified in the studies as being one of the positive products of integrated specialist palliative care $(30-33,43,49,51,52)$. Skill-building was especially important for ward team members without formal training in palliative care $(30,32$, 43). Studies reported that ward staff found integrated specialist palliative care contributed to their education, with skill-building occurring chiefly through observation of the specialist palliative care team during a consultation $(30,32,33,43,48,49)$. Learning and the acquisition of skills by ward staff was demonstrated by an increased understanding of the role of the specialist palliative care team, more appropriate referrals to specialist palliative care, and ward staff's increased capacity to provide generalist palliative care services (48, $49,51)$.

'Deskilling' refers to the fear that the integration of specialist palliative care could prevent ward staff from learning skills to provide comprehensive end of life care themselves, or that skills once acquired could be lost from lack of regular practice $(30,32,33,36,38,40$, 42). Senior level, more experienced staff reported being more concerned about deskilling than their less experienced, junior level staff counterparts $(30,32,36)$. Study results revealed that deskilling was actually mitigated by specialist palliative care integration, with referrers who partnered with specialist palliative care citing higher levels of comfort with and involvement in the holistic management of symptoms than infrequent or non-referrers (35, $36,42,44,48,50-52)$. Respondents were more able to provide front-line, generalist palliative care to their patients as a result of integrating specialist palliative care regardless of disease type, country, hospital size, or specialist palliative care team membership. 
Studies listed several operational items which health and social care providers perceived as facilitating collaboration with specialist palliative care teams. These items included visibility, ease of engagement, access, communication, and ability to provide continuity of care. Regarding visibility, ward teams desire specialist palliative care teams to be highly evident throughout the hospital, frequently being seen on the wards, and being available to round or meet with the ward teams $(35,36,38,48)$. Studies indicated that ward teams want easy access to the specialist palliative care team, which includes having specialist palliative care be timely and responsive when a request is made, preferably seeing the patient and posting a note the day of the request $(35,36,38,45-48)$. Several studies reported staff's desire to have specialist palliative care services available off hours and on weekends $(35,41,48,51$, 52). Frequent communication was cited in most of the studies as fostering collaboration with specialist palliative care, allowing the swift implementation of recommendations, and producing a workable plan of care for the patient (33-36, 38, 41, 47-49, 51). Communication consisted of in-person conversations at the initiation of the request, throughout the care of the patient, and at the completion of the referral; formal referrals made via phone, through an electronic medical record, or in person; informal referrals via phone or by stopping the specialist palliative care professional in the hallway for an 'off the record' conversation to obtain recommendations for patient care; specialist palliative care team participation in multidisciplinary patient care rounds; and brief, timely (same-day) notes with recommendations for care in the patient's medical record $(35,36,38,41,48,49)$. Lastly, integrating specialist palliative care was viewed as a means for facilitating continuity of care for patients, as specialist palliative care teams were able to follow patients from one ward to another, and bridge inpatient, outpatient, and community settings $(33,35,37,38,41,45,48$, 50). The above factors amplified the referring team's perception of specialist palliative care as helpful and increased their willingness to integrate specialist services into patient care.

Studies cited the desirability of multiprofessional specialist palliative care teams (35, 41, 46, 49-51). Generalist teams utilised multidisciplinary specialist palliative care teams, 
Firn, Preston, and Walshe

when present, as a means to quickly and efficiently involve multiple disciplines to simultaneously give input on a case and impact patient outcomes. Specialist palliative care teams with more than one discipline (i.e. physicians, nurses, and social workers) seemed to be preferred over homogeneous (i.e. only nurses) teams $(35,41,49-51)$. Although this preference is difficult to explore further or relate to country, disease type, generalist provider type or hospital size, as half of the studies did not describe specialist palliative care team membership. Regardless of multiprofessional membership, specialist palliative care teams were recognised for their skills in the management of complicated physical symptoms and complex psychosocial and family situations, as well as their ability to assist teams and patients and families with difficult medical decisions (31-34, 36-39, 43, 45-47).

Role confusion, however, could also result when a number of disciplines were involved. Several studies indicated ward teams were confused about their own roles versus the role of the specialist palliative care team when two people of the same discipline were involved in a patient's care (i.e. ward nurse vs. specialist palliative care nurse) $(31-33,45$, $49,51)$. Confusion about roles also stemmed from many teams struggling with the basic definition and understanding of specialist palliative care in these studies, which also contributed to confusion about when and how to integrate specialist services and when to transition from generalist palliative care to specialist palliative care $(31,34,37,39,40,49$ 51). The confusion in the definition of and timing for integration of specialist palliative care persisted even for hospitals with well-established specialist palliative care teams.

\section{Discussion}

Generalists experienced collaboration with hospital-based specialist palliative care teams as beneficial yet challenging at times. As with studies exploring specialist palliative care collaboration in the outpatient and community settings the issues of model of care, perception of expertise, and professional autonomy, as well as the challenges of determining the necessity and timing of specialist palliative care involvement, were identified $(20-22,54-$ 59). Consistent with studies conducted outside of the hospital, communication and 
clarification or roles between generalists and the specialist palliative care team were important for reducing power struggles between providers, minimizing role confusion, and facilitating multidisciplinary collaboration (20, 21, 54-58, 60-62). Additionally, similar to studies in the outpatient and community settings, education and skill-building were recognised as important aspects of satisfaction for referring teams and were viewed as one of the largest benefits of integrating the multiprofessional specialist palliative care (63-65). Including generalist ward staff to the highest level of their ability through encouraging those who are reluctant about their capacity to effectively contribute and allowing those who are more experienced to exercise their own expertise to the fullest extent, appeared to foster collaboration between the referring team and specialist palliative care teams.

Unlike the community setting, the opportunities for role confusion and the need for role clarification may be increased as hospital-based generalist and specialist professionals enter a patient's room in quick succession of one another. Likewise, skill-building occasions may also be increased by the inpatient setting. Different professions are in close physical proximity to and frequently interact with each other, often in the same room at the same time, thus able to observe and learn from one another. Greater attention to communication also becomes more necessary in the inpatient setting as the acute nature of the patient's condition may change rapidly throughout the day. A larger number of professional care providers are usually involved in a patient's care at the same time in the hospital setting, potentially leading to higher chances of mistakes and misunderstandings if teams are not communicating well with each other. The busyness of hospital setting also carries an increased opportunity for interruptions and a high amount of competing demands for ward staff who often care for several patients at the same time, additionally making frequent communication essential.

In the community setting generalists have reported the importance of the responsiveness of the specialist palliative care team (20). In the hospital setting, potentially even more so than in the community setting, responsiveness, visibility, and availability of the 
Firn, Preston, and Walshe

specialist palliative care team were vital for the successful integration of specialist palliative care. Hospital-based generalists, like community generalist, wanted easy access to specialist palliative care teams but they often need a much more rapid response to their requests. Patients are admitted to the hospital for acute problems which cannot be managed in another setting. Acute problems require swift reactions. Both the generalist providers and specialist palliative care team are located on site. The urgency of patient need and the location of the specialist palliative care team may gave increased the value generalists' apply to the responsiveness of the specialist team, making timely responses and communication even more important.

Generalists' perceptions of their own role shaped when and how they utilised specialist palliative care services. Integration of specialist palliative care services occurred earlier in the disease process when involvement was viewed as a continuation of generalists' roles. Historically generalists, such as oncologists, have had established relationships with specialist palliative care, this long term familiarity may make them more comfortable with early integration $(66,67)$. In the future, as other sub-specialties, such as cardiology, interact and become more familiar with specialist palliative care services they too may become increasingly more comfortable with earlier integration $(66,68)$. Like previous studies on collaboration amongst interdisciplinary teams, collaboration between generalist and specialist palliative care teams was enhanced when individuals frequently worked together and were able to develop mutual knowledge $(69,70)$. This level of collaboration and mutual development of knowledge may have been specifically possible in and facilitated by the hospital setting. More so than the outpatient setting, the inpatient setting may have allowed for increased frequency of contact between generalists and specialist palliative care teams. Similar to other studies on teamwork, joint decision making and both formal and informal exchanges further improved communication between generalist and specialist palliative care teams $(70,71)$. In addition, two-way communication channels across team boundaries and with the larger organisation fostered the effectiveness of the teams' functions $(7,70)$. 
Firn, Preston, and Walshe

\section{Limitations}

There are several limitations to this review. The synthesis was conducted by only one reviewer which limits the objectiveness and introduces opportunity for error. Whilst a narrative synthesis approach supports and was designed to manage heterogeneous studies, the heterogeneous nature of the studies adds an element of difficulty to synthesizing the information well. The potential for bias through over representing one study versus another, whilst carefully scrutinised, also remains a possibility. The variety in the key terms and working definitions in the literature used to refer to specialist palliative care teams made searching for articles and having a discussion about the role and scope of the services they provide challenging. Responses from the different generalist palliative care professionals were often combined or not specifically identified in the studies. Physicians, nurses, social workers, etc. might have dissimilar perceptions of the various themes. These nuances are lost when results are pooled which limits the results of this review. Further distinction between trust and expertise is also needed. The use of studies with quantitative methods exploring participants' perceptions could be potentially limiting too, as a quantitative approach is not the best approach to answer such nuanced questions. Even with these concerns the quantitative studies are informative and useful for the purposes of this review. Whilst a qualitative method may be more suited to answering questions of perception, the qualitative studies included in the review also have limitations. From a participant standpoint, the studies were often limited to a single institution where it would not be possible to reach data saturation before all relative participants have been included. Given the practicalities involved in qualitative research and the confines of a single institution, it appears that the qualitative studies were able to adequately address the research question and their results are informative for clinical practice.

\section{Strengths}

Despite the limitations listed above the included studies and synthesis approach appear to satisfactorily answer the review question. The review was conducted rigorously and is 
replicable. The synthesis question was well addressed by the narrative synthesis approach. The review findings are useful for practice, albeit they should be applied with a degree of caution. By utilising an identifiable and tested approach to the synthesis the reliability of the synthesis results are further strengthened. The rigor of the literature search resulted in the comprehensive identification of relevant studies. Inclusion of all applicable studies in the synthesis allowed for a broad and full understanding of the phenomenon under review. Whilst the synthesis was conducted by one person measures were taken to reduce bias by having all authors discuss the inclusion of relevant articles, as well as the identification and interpretation of themes. Even with the heterogeneous nature of the studies the findings appear similar. Moreover, the findings from the quantitative studies mirror those of the qualitative studies and vice versa, adding further strength to the synthesis. The themes identified here occur consistently over time, across different populations, and in different countries. The heterogeneity of the populations and of the settings gives encouragement regarding the vigor of the findings and their applicability to a variety of countries, hospital settings, specialist palliative care team membership, disease types, and healthcare professionals.

\section{Future Research}

As a result of this review there are several areas where future research could be conducted. Specialist palliative care activities and the ward team's experiences of integrating specialist palliative care from countries not included in the review studies could be explored. The experiences of allied health personnel (physiotherapy, dietitians, speech and language pathology, etc.) could use further investigation as well as they were minimally represented in the studies' samples and their responses were often combined with other disciplines. Further exploration of the areas of expertise and trust and their roles in facilitating collaboration would also be beneficial. Additional research is also merited about the perceptions and experiences of health and social care providers in other sub-specialty areas of medicine, including further investigation of professionals from the fields identified in the review studies 
(Cardiology, Neurology, Oncology, Surgery, Vascular Surgery, and Physical Rehabilitation). For example, Kavalieratos et al (68) found in 2014 that Cardiologists wanted to integrate specialist palliative care services and were not concerned that patients might be 'stolen' by the specialist palliative care team (68). It is possible that hospital-based Neurology, Oncology, Surgery, Vascular Surgery, and Physical Rehabilitation providers' perceptions of specialist palliative care integration may have also evolved since the review studies were published. Lastly, the focus of these studies and the review as a whole is on the providers' perceptions of collaboration. Data are not available to draw specific conclusions about the impact of either the integrated or linear care models on patient care outcomes. Research exploring the impact of specialist palliative care integration and collaboration on patient experiences and outcomes continues to be necessary (20).

\section{Conclusion}

Integration of hospital-based specialist palliative care teams seems to enhance collaboration between the referring generalist ward team and specialist palliative care. Collaboration is fostered when each team recognises and supports the expertise of the other. Facilitators of collaboration include: effective communication between both groups of professional caregivers, determination of complementary roles, and shared problem-solving responsibilities.

\section{Acknowledgements}

This research received no specific grant from any funding agency in the public, commercial, or not-for-profit sectors. It was undertaken as part of the requirements for a $\mathrm{PhD}$ in Palliative Care.

\section{Conflict of Interest}

The Authors declare that there is no conflict of interest. 
Firn, Preston, and Walshe

\section{References}

1. Weissman DE. The growth of hospital-based palliative care. J Palliat Med. 2001;4(3):307-8.

2. O'Mahony S, Blank AE, Zallman L, Selwyn PA. The benefits of a hospital-based inpatient palliative care consultation service: preliminary outcome data. J Palliat Med. 2005;8(5):1033-9.

3. Twaddle ML, Maxwell TL, Cassel JB, Liao S, Coyne PJ, Usher BM, et al. Palliative care benchmarks from academic medical centers. J Palliat Med. 2007;10(1):86-98.

4. Auerbach C, Mason SE, Laporte HH. Evidence that Supports the Value of Social Work in Hospitals. Social work in health care. 2007;44(4):17-32.

5. Waller R. Coordinated, Intensive Medical, Social, and Behavioral Health Services Improve Outcomes and Reduce Utilization for Frequent Emergency Department Users. Agency for Healthcare Research and Quality, 2011.

6. Goodwin N, Smith J, Davies A, Perry C, Rosen R, Dixon A, et al. A report to the Department of Health and the NHS Future Forum. London: The Kings Fund, 2011.

7. Firth-Cozens J. Cultures for improving patient safety through learning: the role of teamwork. Quality Health Care. 2001;10(Suppl 2):ii26-ii31.

8. Tam S, Suen L, Ho K, Lee D. Assessing the safety and teamwork climate of intensive care staff. The World of Critical Care Nursing. 2011;8(1).

9. Sexton J, Thomas E, Helmreich R. Error, stress, and teamwork in medicine and aviation: cross sectional surveys. BMJ. 2000;320(7237):745-9.

10. Knaus WA, Draper EA, Wagner DP, Zimmerman JE. An evaluation of outcomes from intensive care in major medical centers. Annals of Internal Medicine. 1986;104:410-8.

11. Rubenstein LS, Josephson KR, Wieland GD. Effectiveness of a geriatric evaluation unit: a randomized clinical trial. North Eastern Journal of Medicine. 1984;311:1664-70.

12. Barker WH, Williams TF, Zimmer JG. Geriatric consultation teams in acute hospitals: Impact on back-up of elderly patients. Journal of American Geriatrics Society. 1985;33:422-

8.

13. Baggs JG, Ryan SA. Intensive care unit nurse-physician collaboration and nurse satisfaction. Nursing Economics. 1990;8:386-92.

14. Rafferty A, Ball J, Aiken L. Are teamwork and professional autonomy compatible, and do they result in improved hospital care? Quality in Health Care. 2001;10(Suppl II):ii32-ii7.

15. Sommers LS, Marton KI, Barbaccia JC, Randolph J. PHysician, nurse, and social worker collaboration in primary care for chronically ill seniors. Archives of Internal Medicine. 2000;160(12):1825-33.

16. Abramson J, Mizrahi T. When social workers and physicians collaborate: Positive and negative interdisciplinary experiences. Social Work. 1996;41(3):270-81.

17. Barr O. Interdisciplinary teamwork: consideration of the challenges. British Journal of Nursin. 1997;6(17):1005-10.

18. Butterill D, O'Hanlon J, Book $\mathrm{H}$. When the system is the problem, don't blame the patient: problems inherent in the interdisciplinary inpatient team. Canadian Journal of Psychiatry. 1992;37(3):168-72.

19. Walshe C, Todd C, Caress A, Chew-Graham C. Patterns of Access to Community Palliative Care Services: A Literature Review. Journal of pain and symptom management. 2009;37(5):884-912.

20. Gardiner C, Gott M, Ingleton C. Factors supporting good partnership working between generalist and specialist palliative care services: a systematic review. $\mathrm{Br} \mathrm{J}$ Gen Pract. 2012;62(598):e353-62.

21. Ahmed N, Bestall JC, Ahmedzai SH, Payne SA, Clark D, Noble B. Systematic review of the problems and issues of accessing specialist palliative care by patients, carers and health and social care professionals. Palliat Med. 2004;18(6):525-42.

22. Oishi A, Murtagh FEM. The challenges of uncertainty and interprofessional collaboration in palliative care for non-cancer patients in the community: A systematic review 
Firn, Preston, and Walshe

of views from patients, carers and health-care professionals. Palliative medicine. 2014;28(9):1081-98.

23. von Gunten CF, Weissman DE. Consultation etiquette in palliative care \#266. J Palliat Med. 2013;16(5):578-9.

24. Meier DE, Beresford L. Consultation etiquette challenges palliative care to be on its best behavior. J Palliat Med. 2007;10(1):7-11.

25. Moher D, Liberati A, Tetzlaff J, Altman DG, Group P. Preferred reporting items for systematic reviews and meta-analyses: the PRISMA statement. BMJ. 2009;339:b2535.

26. Center to Advance Palliative Care. Journals 2014 [31 December 2014]. Available from: http://www.capc.org/research-and-references-for-palliative-care/journals.

27. Popay J, Roberts H, Sowden A, Petticrew M, Arai L, Rodgers M, et al. Guidance on the Conduct of Narrative Synthesis in Systematic Reviews In: Programme EM, editor.: ESRC Methods Programme; 2006.

28. Hawker S, Payne S, Kerr C, Hardey M, Powell J. Appraising the evidence: reviewing disparate data systematically. Qual Health Res. 2002;12(9):1284-99.

29. Claessens P, Menten J, Schotsmans P, Broeckaert B. Palliative Sedation: A Review of the Research Literature. Journal of pain and symptom management. 2008;36(3):310-33.

30. Jack B, Oldham J, Williams A. Do hospital-based palliative care clinical nurse specialists de-skill general staff? Int J Palliat Nurs. 2002;8(7):336-40.

31. Hibbert D, Hanratty B, May C, Mair F, Litva A, Capewell S. Negotiating palliative care expertise in the medical world. Soc Sci Med. 2003;57(2):277-88.

32. Jack B, Oldham J, Williams A. A stakeholder evaluation of the impact of the palliative care clinical nurse specialist upon doctors and nurses, within an acute hospital setting.

Palliat Med. 2003;17(3):283-8.

33. Mytton EJ, Adams A. Do clinical nurse specialists in palliative care de-skill or empower general ward nurses? Int J Palliat Nurs. 2003;9(2):64-72.

34. Rodriguez KL, Barnato AE, Arnold RM. Perceptions and utilization of palliative care services in acute care hospitals. J Palliat Med. 2007;10(1):99-110.

35. Enguidanos S, Housen P, Goldstein R, Vesper E, Allen J, Braun W. Physician and nurse perceptions of a new inpatient palliative care consultation project: implications for education and training. J Palliat Med. 2009;12(12):1137-42.

36. Ewing G, Farquhar M, Booth S. Delivering palliative care in an acute hospital setting: views of referrers and specialist providers. Journal of pain and symptom management. 2009;38(3):327-40.

37. Le BH, Watt JN. Care of the dying in Australia's busiest hospital: benefits of palliative care consultation and methods to enhance access. J Palliat Med. 2010;13(7):855-60.

38. Norton SA, Powers BA, Schmitt MH, Metzger M, Fairbanks E, Deluca J, et al. Navigating tensions: integrating palliative care consultation services into an academic medical center setting. Journal of pain and symptom management. 2011;42(5):680-90.

39. Burton CR, Payne S. Integrating palliative care within acute stroke services: developing a programme theory of patient and family needs, preferences and staff perspectives. BMC Palliat Care. 2012;11:22.

40. Gott M, Seymour J, Ingleton C, Gardiner C, Bellamy G. 'That's part of everybody's job': the perspectives of health care staff in England and New Zealand on the meaning and remit of palliative care. Palliat Med. 2012;26(3):232-41.

41. Lane $\mathrm{H}$, Weil J, Jelinek GA, Boughey M, Marck $\mathrm{CH}$, Weiland TJ, et al. Ideal care and the realities of practice: interdisciplinary relationships in the management of advanced cancer patients in Australian emergency departments. Supportive Care in Cancer. 2014;22(4):1029-35.

42. Dharmasena HP, Forbes K. Palliative care for patients with non-malignant disease: will hospital physicians refer? Palliat Med. 2001;15(5):413-8.

43. Salomon L, Belouet C, Vinant-Binam P, Sicard D, Vidal-Trécan G. A terminal care support team in a Paris university hospital: care providers' views. J Palliat Care.

2001;17(2):109-16. 
44. Cherny NI, Catane R, Care ESoMOToPaS. Attitudes of medical oncologists toward palliative care for patients with advanced and incurable cancer: report on a survery by the European Society of Medical Oncology Taskforce on Palliative and Supportive Care. Cancer. 2003;98(11):2502-10.

45. Turner-Stokes L, Sykes N, Silber E, Khatri A, Sutton L, Young E. From diagnosis to death: exploring the interface between neurology, rehabilitation and palliative care in managing people with long-term neurological conditions. Clin Med. 2007;7(2):129-36. 46. Johnson MJ, Maccallum A, Butler J, Rogers A, Sam E, Fuller A, et al. Heart failure specialist nurses' use of palliative care services: a comparison of surveys across England in 2005 and 2010. Eur J Cardiovasc Nurs. 2012;11(2):190-6.

47. Armstrong $B$, Jenigiri $B$, Hutson SP, Wachs PM, Lambe CE. The impact of a palliative care program in a rural Appalachian community hospital: a quality improvement process. Am J Hosp Palliat Care. 2013;30(4):380-7.

48. Carter H, Mckinlay E, Scott I, Wise D, MacLeod R. Impact of a hospital palliative care service: perspective of the hospital staff. J Palliat Care. 2002;18(3):160-7.

49. Dowell L. Multiprofessional palliative care in a general hospital: education and training needs. Int J Palliat Nurs. 2002;8(6):294-303.

50. Snow CE, Varela BR, Pardi DA, Adelman RD, Said S, Reid MC. Identifying factors affecting utilization of an inpatient palliative care service: a physician survey. J Palliat Med. 2009;12(3):231-7.

51. Ward AM, Agar M, Koczwara B. Collaborating or co-existing: a survey of attitudes of medical oncologists toward specialist palliative care. Palliat Med. 2009;23(8):698-707.

52. Sasahara T, Miyashita M, Umeda M, Higuchi H, Shinoda J, Kawa M, et al. Multiple evaluation of a hospital-based palliative care consultation team in a university hospital: Activities, patient outcome, and referring staff's view. Palliative \& Supportive Care. 2010;8(1):49-57.

53. Hibberd $P$. The primary/secondary interface. Cross-boundary teamwork-missing-link for seamless care? Journal of Clinical Nursing. 1998;7(3):274-82.

54. Shipman C, Gysels M, White P, Worth A, Murray SA, Barclay S, et al. Improving generalist end of life care: national consultation with practitioners, commissioners, academics, and service user groups. BMJ. 2008;337:a1720.

55. Goldschmidt D, Groenvold M, Johnsen AT, Strömgren AS, Krasnik A, Schmidt L. Cooperating with a palliative home-care team: expectations and evaluations of GPs and district nurses. Palliat Med. 2005;19(3):241-50.

56. Shipman C, Addington-Hall J, Barclay S, Briggs J, Cox I, Daniels L, et al. How and why do GPs use specialist palliative care services? Palliat Med. 2002;16(3):241-6.

57. Hanratty B, Hibbert D, Mair F, May C, Ward C, Capewell S, et al. Doctors' perceptions of palliative care for heart failure: focus group study. BMJ. 2002;325(7364):5815.

58. Pavlish C, Ceronsky L. Oncology nurses' perceptions about palliative care. Oncol Nurs Forum. 2007;34(4):793-800.

59. Walshe C, Chew-Graham C, Todd C, Caress A. What influences referrals within community palliative care services? A qualitative case study. Soc Sci Med. 2008;67(1):13746.

60. Walshe C, Todd C, Caress A-L, Chew-Graham C. Judgements aboutfellow professionalsand the management of patientsreceiving palliative care in primary care:a qualitative study. British Journal of General Practice. 2008;58:264-72.

61. Hanratty B, Hibbert D, Mair F, May C, Ward C, Corcoran G, et al. Doctors' understanding of palliative care. Palliat Med. 2006;20(5):493-7.

62. Brueckner T, Schumacher M, Schneider N. Palliative care for older people - exploring the views of doctors and nurses from different fields in Germany. BMC Palliat Care. 2009;8:7.

63. Llamas KJ, Llamas M, Pickhaver AM, Piller NB. Provider perspectives on palliative care needs at a major teaching hospital. Palliat Med. 2001;15(6):461-70. 
64. Schneider N, Ebeling $\mathrm{H}$, Amelung VE, Buser K. Hospital doctors' attitudes towards palliative care in Germany. Palliat Med. 2006;20(5):499-506.

65. Campion-Smith C, Austin H, Criswick S, Dowling B, Francis G. Can sharing stories change practice? A qualitative study of an interprofessional narrative-based palliative care course. J Interprof Care. 2011;25(2):105-11.

66. Lindvall C, Hultman TD, Jackson VA. Overcoming the Barriers to Palliative Care Referral for Patients With Advanced Heart Failure. Journal of the American Heart Association. 2014;3(1).

67. Clark D. From margins to centre: a review of the history of palliative care in cancer. The Lancet Oncology. 2007;8(5):430-8.

68. Kavalieratos D, Mitchell EM, Carey TS, Dev S, Biddle AK, Reeve BB, et al. "Not the 'grim reaper service'": an assessment of provider knowledge, attitudes, and perceptions regarding palliative care referral barriers in heart failure. J Am Heart Assoc.

2014;3(1):e000544.

69. Michan S, Rodger S. Characteristics of effective teams:a literature review. Australian Health Review. 2000;23(3):201-8.

70. Nancarrow SA, Booth A, Ariss S, Smith T, Enderby P, Roots A. Ten principles of good interdisciplinary team work. Human Resources for Health. 2013;11:19-.

71. Headrick L, Wilcock $P$, Batalden P. Interprofessional working and continuing medical education. BMJ. 1998;316:771-4. 


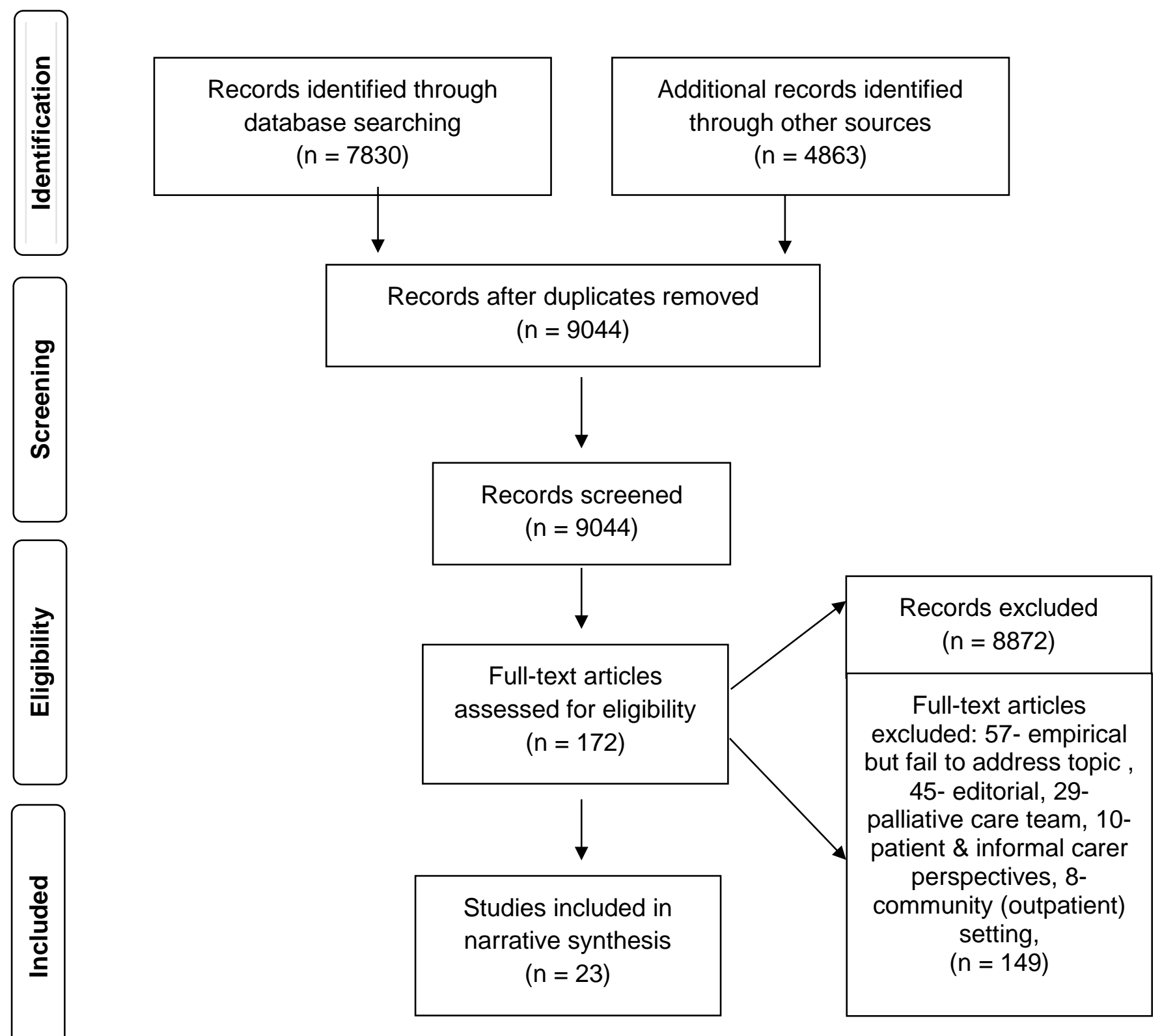

Figure 1: PRISMA Flow Diagram Study Selection 
- An acute care hospital is a 'short-term hospital where medical staff and all necessary personnel provide diagnosis, care and treatment of a wide range of acute conditions (1).' Patients admitted to an acute care hospital are considered 'inpatient' when they spend at least one night in the hospital (2).

- Hospital-based specialist palliative care teams do not assume full responsibility for or take over the care of the patient; rather they liaise with the ward team to provide care to patients by meeting with the patient and making recommendations based on patient needs and goals which the ward team then operationalizes.

- Professional collaboration in healthcare can be defined as health and social care providers (physicians, nurses, social workers, etc.) taking on complementary roles to cooperatively work together through sharing problem-solving responsibilities and making decisions to formulate and carry out plans for patient care $(3,4)$.

- Multiprofessional teams are defined as a group of professionals from a variety of health and social care disciplines, i.e. specialized nurses and a specialist physician in palliative care, psychologist, physiotherapist, and/or spiritual counselor and social worker, who collaborate to provide patient care (5).

1. Connecticut Department of Health. The Health of Connecticut Hospitals: Hospitals Today. In: (OHCA) OoHCA, editor. 2001.

2. Medicare. Are you a hospital inpatient or outpatient. 2014.

3. Baggs JG, Schmitt MH. Collaboration between nurses and physicians. Image J Nurs Sch. 1988;20(3):145-9.

4. Fagin CM. Collaboration between nurses and physicians: no longer a choice. Acad Med. 1992;67(5):295-303.

5. Vissers KCP, van den Brand MWM, Jacobs J, Groot M, Veldhoven C, Verhagen C, et al. Palliative Medicine Update: A Multidisciplinary Approach. Pain Practice. 2013;13(7):576-88. 


\section{Table 2: Terms used in search strategy}

1) Identification of palliative care Terminally ill patients OR Palliative care OR Terminal care OR Hospice OR End of life OR Death OR Dying

2) Professional personnel

Social work OR Doctor OR Physician OR Nurse OR Medical staff OR Medical personnel OR Team OR Patient care team OR Health team OR Consultants OR Hospital medical staff OR Hospital nursing staff OR Allied health personnel OR Specialist palliative care OR Generalist palliative care OR Multidisciplinary OR Interdisciplinary OR Interprofessional

3) Attitude

Attitude OR Perception OR Attitude of health personnel OR Experience OR View

4) $\underline{\text { Action }}$

Professional consultation OR Interdisciplinary treatment approach OR Communication OR Collaboration OR Decision making OR Cooperation OR Cooperative behaviour OR Interdisciplinary communication OR Interprofessional relations OR Joint practice OR Referral and consultation OR Shared care

5) Location

Inpatient OR Hospitalized patients OR Acute care OR Hospital-based 
Table 3: Data Extraction and Study Quality

\begin{tabular}{|c|c|c|c|c|c|c|}
\hline $\begin{array}{l}\text { Author (Year) } \\
\text { Cntry, Score }\end{array}$ & Research Question & Participants & Method & $\begin{array}{l}\text { Pall Care } \\
\text { Team }\end{array}$ & Themes & Key Findings \\
\hline $\begin{array}{l}\text { Dharmasena } \\
\text { and Forbes } \\
(2001) \\
\text { Wales , } 25\end{array}$ & $\begin{array}{l}\text { Will doctors refer non- } \\
\text { cancer patients to } \\
\text { palliative care? }\end{array}$ & 78 consultants & $\begin{array}{l}\text { Postal survey, } 8 \\
\text { items. Analysis } \\
\text { not described. }\end{array}$ & $\begin{array}{l}\text { Not } \\
\text { described }\end{array}$ & $\begin{array}{l}\text { Model of Care; Professional } \\
\text { Onus; Expertise \& Trust; } \\
\text { Skill Building vs. Deskilling }\end{array}$ & $\begin{array}{l}\text { Integrated care preferred. Cardiology concerned palliative } \\
\text { care may not have the disease -specific expertise needed. } \\
\text { All doctors should be skilled in palliative care. Concern for } \\
\text { deskilling and patient abandonment. }\end{array}$ \\
\hline $\begin{array}{l}\text { Salomon et al. } \\
\text { (2001) } \\
\text { France, } 30\end{array}$ & $\begin{array}{l}\text { To describe the current } \\
\text { management of } \\
\text { terminally ill patients } \\
\text { from care providers' } \\
\text { viewpoint. }\end{array}$ & $\begin{array}{l}31 \text { physicians } \\
16 \text { nurses }\end{array}$ & $\begin{array}{l}\text { Structured self- } \\
\text { administered } 33 \\
\text { item survey. } \\
\text { SPSS used for } \\
\text { analysis. }\end{array}$ & $\begin{array}{l}\text { Physician, } \\
\text { nurse, } \\
\text { psychologist. }\end{array}$ & $\begin{array}{l}\text { Model of Care; Skill Building } \\
\text { vs. Deskilling; Specialist } \\
\text { Palliative Care Operations }\end{array}$ & $\begin{array}{l}\text { Integrated care provided for skill-building opportunities. } \\
\text { Ward team desired expertise of specialist palliative care. } \\
\text { Availability of specialist palliative care important. }\end{array}$ \\
\hline $\begin{array}{l}\text { Carter et al. } \\
(2002) \\
\text { New Zealand, } \\
29\end{array}$ & $\begin{array}{l}\text { To determine health } \\
\text { professionals' } \\
\text { perception of the } \\
\text { service's impact on } \\
\text { patients, families, and } \\
\text { staff, and areas that } \\
\text { need improvement. }\end{array}$ & $\begin{array}{l}127 \text { doctors } \\
242 \text { nurses } \\
11 \text { social workers }\end{array}$ & $\begin{array}{l}\text { Postal survey, } 5 \\
\text { point Likert scale } \\
\text { \& Yes/No } \\
\text { questions. } \\
\text { EPI6 used for } \\
\text { analysis. }\end{array}$ & $\begin{array}{l}\text { Full time } \\
\text { nurse, part- } \\
\text { time } \\
\text { physician. }\end{array}$ & $\begin{array}{l}\text { Model of Care; Skill Building } \\
\text { vs. Deskilling; Specialist } \\
\text { Palliative Care Operations }\end{array}$ & $\begin{array}{l}\text { Integrated care desired. Skill-building, communication, } \\
\text { availability of services, and ease of access important } \\
\text { aspects of involving specialist palliative care. }\end{array}$ \\
\hline $\begin{array}{l}\text { Dowell (2002) } \\
\text { England , } 27\end{array}$ & $\begin{array}{l}\text { To establish a baseline } \\
\text { of palliative care } \\
\text { knowledge, attitudes, } \\
\text { and practices of } \\
\text { multidisciplinary hospital } \\
\text { staff. }\end{array}$ & $\begin{array}{l}\text { Focus group: } 2 \\
\text { nurses, } 1 \text { doctor, } 1 \\
\text { pharmacist, } 3 \\
\text { chaplains, } 1 \text { social } \\
\text { worker, } 1 \text { OT, } 1 \text { PT. } \\
\text { Questionnaire } 30 \\
\text { people. }\end{array}$ & $\begin{array}{l}\text { Focus groups, } \\
16 \text { item survey. } \\
\text { Analysis not } \\
\text { described. }\end{array}$ & $\begin{array}{l}\text { Not } \\
\text { described. }\end{array}$ & $\begin{array}{l}\text { Model of Care; Professional } \\
\text { Onus; Expertise \& Trust; } \\
\text { Skill Building vs. Deskilling; } \\
\text { Specialist Palliative Care } \\
\text { Operations }\end{array}$ & $\begin{array}{l}\text { Integrated care desired by some but experienced as } \\
\text { challenging by others. Role differentiation unclear. Ward } \\
\text { and specialist palliative care team expertise sometimes at } \\
\text { odds or of concern. Trust impacted by lack of inclusion of } \\
\text { or communication with ward team in planning for patient } \\
\text { care. }\end{array}$ \\
\hline $\begin{array}{l}\text { Jack et al. } \\
\text { (2002) } \\
\text { England, } 29\end{array}$ & $\begin{array}{l}\text { To explore generalists' } \\
\text { perception of de-skilling. }\end{array}$ & $\begin{array}{l}19 \text { nurses - } \\
\text { managers and ward } \\
\text { staff, } 4 \text { consultants, } \\
4 \text { doctors, } 4 \text { CNS } \\
\text { SPC. }\end{array}$ & $\begin{array}{l}\text { Open-ended } \\
\text { interviews } \\
\text { Analyzed using } \\
\text { case/cross-case } \\
\text { analysis. }\end{array}$ & $\begin{array}{l}4 \text { CNSs, a } \\
\text { consultant } \\
\text { and } \\
\text { specialist } \\
\text { registrar. }\end{array}$ & $\begin{array}{l}\text { Professional Onus; } \\
\text { Expertise \& Trust }\end{array}$ & $\begin{array}{l}\text { Concern for deskilling; Junior staff less concerned than } \\
\text { senior staff. Desire from ward team to maintain generalist } \\
\text { palliative care skills. }\end{array}$ \\
\hline $\begin{array}{l}\text { Cherny et al. } \\
\text { (2003) } \\
\text { Europe, } \\
\text { USA, Asia, } \\
\text { Australia, } \\
\text { Africa, } 35\end{array}$ & $\begin{array}{l}\text { To describe Oncologists } \\
\text { involvement and } \\
\text { attitudes toward } \\
\text { palliative care of patients } \\
\text { with advanced cancer }\end{array}$ & 895 physicians & $\begin{array}{l}\text { Postal survey. } \\
\text { Multivariate } \\
\text { analysis. }\end{array}$ & $\begin{array}{l}\text { Not } \\
\text { described. }\end{array}$ & $\begin{array}{l}\text { Model of Care; Professional } \\
\text { Onus; Expertise vs. Trust }\end{array}$ & $\begin{array}{l}\text { Integrated care highly valued and sought by most. Want } \\
\text { to share responsibility of care. Role conflict and confusion } \\
\text { about who is best at managing oncology patients' } \\
\text { palliative care needs. Issues of expertise and trust, unsure } \\
\text { palliative care can manage their patients. }\end{array}$ \\
\hline $\begin{array}{l}\text { Hibbert et al. } \\
\text { (2003) } \\
\text { England, } 30\end{array}$ & $\begin{array}{l}\text { Explore doctors' views } \\
\text { of developing palliative } \\
\text { care for patients with } \\
\text { heart failure }\end{array}$ & $\begin{array}{l}7 \text { focus groups of } \\
\text { physicians }\end{array}$ & $\begin{array}{l}\text { Open-ended } \\
\text { interviews. } \\
\text { Thematic } \\
\text { analysis. }\end{array}$ & $\begin{array}{l}\text { Not } \\
\text { described. }\end{array}$ & $\begin{array}{l}\text { Model of Care; Professional } \\
\text { Onus; Expertise \& Trust; } \\
\text { Skill Building vs. Deskilling, } \\
\text { Specialist Palliative Care } \\
\text { Operations }\end{array}$ & $\begin{array}{l}\text { Linear care more the norm. Referral to palliative care } \\
\text { means failure for cardiologist. Two-way learning process } \\
\text { between palliative medicine and other specialties is } \\
\text { positive experience. Concern that cardiology will not } \\
\text { address palliative needs, trust and expertise are issues. }\end{array}$ \\
\hline
\end{tabular}


Table 3: Data Extraction and Study Quality

\begin{tabular}{|c|c|c|c|c|c|c|}
\hline $\begin{array}{l}\text { Author (Year) } \\
\text { Cntry, Score }\end{array}$ & Research Question & Participants & Method & $\begin{array}{l}\text { Pall Care } \\
\text { Team }\end{array}$ & Themes & Key Findings \\
\hline $\begin{array}{l}\text { Jack et al. } \\
\text { (2003) } \\
\text { England, } 32\end{array}$ & $\begin{array}{l}\text { Explore the impact of } \\
\text { hospital-based palliative } \\
\text { care clinical nurse } \\
\text { specialists on doctors } \\
\text { and nurses }\end{array}$ & $\begin{array}{l}23 \text { nurses } \\
8 \text { physicians }\end{array}$ & $\begin{array}{l}\text { Open-ended } \\
\text { interviews. } \\
\text { Case/cross-case } \\
\text { analysis. }\end{array}$ & $\begin{array}{l}4 \text { clinical } \\
\text { nurse } \\
\text { specialists, } \\
\text { consultant } \\
\text { and registrar } \\
\text { available for } \\
\text { advice via } \\
\text { phone. }\end{array}$ & $\begin{array}{l}\text { Model of Care; Professional } \\
\text { Onus; Expertise \& Trust; } \\
\text { Skill Building vs. Deskilling }\end{array}$ & $\begin{array}{l}\text { Integrated care seen as a positive. Skill-building and } \\
\text { deskilling concerns voiced by staff. Appreciation of } \\
\text { palliative care expertise cited. }\end{array}$ \\
\hline $\begin{array}{l}\text { Mytton and } \\
\text { Adams (2003) } \\
\text { England, 35 }\end{array}$ & $\begin{array}{l}\text { Examine how specialist } \\
\text { and generalist nurses } \\
\text { work together in the } \\
\text { care of terminally ill } \\
\text { patients. }\end{array}$ & $\begin{array}{l}8 \text { generalist nurses } \\
2 \text { nurses from SPC }\end{array}$ & $\begin{array}{l}\text { Open-ended } \\
\text { interviews, case } \\
\text { vignette. } \\
\text { Thematic } \\
\text { analysis. }\end{array}$ & $\begin{array}{l}5 \text { clinical } \\
\text { nurse } \\
\text { specialists. }\end{array}$ & $\begin{array}{l}\text { Model of Care; Professional } \\
\text { Onus; Expertise \& Trust; } \\
\text { Skill Building vs. Deskilling; } \\
\text { Specialist Palliative Care } \\
\text { Operations }\end{array}$ & $\begin{array}{l}\text { Integrated care helpful, however, concern for abdication of } \\
\text { responsibility, deskilling, and role confusion led to more } \\
\text { linear approach to care. Appreciation for specialist } \\
\text { expertise. }\end{array}$ \\
\hline $\begin{array}{l}\text { Rodriguez et } \\
\text { al. (2007) } \\
\text { USA, } 36\end{array}$ & $\begin{array}{l}\text { Explore how physicians } \\
\text { and other health care } \\
\text { providers in acute care } \\
\text { hospital perceive and } \\
\text { utilize palliative care } \\
\text { services. }\end{array}$ & $\begin{array}{l}129 \text { participants: } \\
\text { administrators and } \\
\text { ward staff }\end{array}$ & $\begin{array}{l}\text { Semi-structured } \\
\text { interviews, } \\
\text { ethnographic } \\
\text { observation. } \\
\text { Thematic } \\
\text { analysis. }\end{array}$ & $\begin{array}{l}\text { Not } \\
\text { described. }\end{array}$ & $\begin{array}{l}\text { Model of Care; Professional } \\
\text { Onus, Expertise \& Trust; } \\
\text { Specialist Palliative Care } \\
\text { Operations }\end{array}$ & $\begin{array}{l}\text { Linear care preferred. Role confusion and view that } \\
\text { involving palliative care means failure and abandonment. } \\
\text { Generalists view symptom management as their } \\
\text { responsibility. More referrals to specialist care made when } \\
\text { specialists were seen as being experts and respecting } \\
\text { referring teams' expertise and role. }\end{array}$ \\
\hline $\begin{array}{l}\text { Turner-Stokes } \\
\text { et al. }(2007) \\
\text { UK, } 28\end{array}$ & $\begin{array}{l}\text { To explore the } \\
\text { interaction between } \\
\text { SPC, neurology, and } \\
\text { rehabilitation services. }\end{array}$ & $\begin{array}{l}82 \text { neurologist, } 149 \\
\text { SPC, } \\
53 \text { Rehab physicians }\end{array}$ & $\begin{array}{l}\text { Postal Survey. } \\
\text { Analyzed wl } \\
\text { SPSS, chi- } \\
\text { squared stats, } \\
\text { expected } \\
\text { frequency }>5 \text {. }\end{array}$ & $\begin{array}{l}\text { Not } \\
\text { described. }\end{array}$ & $\begin{array}{l}\text { Model of Care; Professional } \\
\text { Onus; Expertise \& Trust; } \\
\text { Specialist Palliative Care } \\
\text { Operations. }\end{array}$ & $\begin{array}{l}\text { Linear care common. Role confusion, belief that it is } \\
\text { generalist's responsibility to manage symptoms. Easy } \\
\text { access and appreciation of skill needed for specialist } \\
\text { palliative care enabled referrals. }\end{array}$ \\
\hline $\begin{array}{l}\text { Enguidanos et } \\
\text { al. (2009) } \\
\text { USA, } 34\end{array}$ & $\begin{array}{l}\text { To explore Physician } \\
\text { and nurse perceptions of } \\
\text { an inpatient palliative } \\
\text { care team consultation } \\
\text { service after } 1 \text { yr. of } \\
\text { operation }\end{array}$ & $\begin{array}{l}33 \text { participants } 16 \\
\text { physician, } 17 \\
\text { nursing }\end{array}$ & $\begin{array}{l}\text { Focus groups. } \\
\text { Analyzed using } \\
\text { grounded theory. }\end{array}$ & $\begin{array}{l}2 \text { quarter } \\
\text { time } \\
\text { physicians, } \\
\text { one nurse, } \\
\text { and one } \\
\text { social } \\
\text { worker. }\end{array}$ & $\begin{array}{l}\text { Model of Care; Professional } \\
\text { Onus; Expertise \& Trust, } \\
\text { Specialist Palliative Care } \\
\text { Operations }\end{array}$ & $\begin{array}{l}\text { Integration seen as valuable. Responsiveness of } \\
\text { specialist team increased utilisation. Expertise desired, } \\
\text { collaboration enhanced through good communication. } \\
\text { Trust increased by collaboration, inclusion, and skill- } \\
\text { building, decreased by exclusion. }\end{array}$ \\
\hline $\begin{array}{l}\text { Ewing et al. } \\
\text { (2009) } \\
\text { England, } 33\end{array}$ & $\begin{array}{l}\text { Referrers and providers } \\
\text { views of multidisciplinary } \\
\text { SPC in the acute } \\
\text { hospital setting. }\end{array}$ & $\begin{array}{l}5 \text { Junior doctors, } 13 \\
\text { Consultants, } 6 \\
\text { Clinical Nurse } \\
\text { Specialists }\end{array}$ & $\begin{array}{l}\text { In person } \\
\text { interviews, } \\
\text { observation. } \\
\text { Analyzed } \\
\text { thematically } \\
\text { using framework } \\
\text { analysis. }\end{array}$ & $\begin{array}{l}2 \\
\text { consultants, } \\
\text { Associate } \\
\text { Specialist in } \\
\text { palliative } \\
\text { medicine, } 2 \\
\text { Specialist } \\
\text { Registrars, } 5 \\
\text { CNS, } 2 \text { staff. }\end{array}$ & $\begin{array}{l}\text { Model of Care; Professional } \\
\text { Onus; Expertise \& Trust; } \\
\text { Skill Building vs. Deskilling; } \\
\text { Specialist Palliative Care } \\
\text { Operations }\end{array}$ & $\begin{array}{l}\text { Integrated care desired. Oncologists view their role as first } \\
\text { line for symptom management; collaborate with specialist } \\
\text { services if unable to control symptoms themselves. Want } \\
\text { to maintain ownership of and relationship with patient. } \\
\text { Some concern for deskilling. Ease of access important. }\end{array}$ \\
\hline
\end{tabular}




\begin{tabular}{|c|c|c|c|c|c|c|}
\hline $\begin{array}{l}\text { Author (Year) } \\
\text { Cntry, Score }\end{array}$ & Research Question & Participants & Method & $\begin{array}{l}\text { Pall Care } \\
\text { Team }\end{array}$ & Themes & Key Findings \\
\hline $\begin{array}{l}\text { Snow et al. } \\
\text { (2009) USA, } \\
32\end{array}$ & $\begin{array}{l}\text { To better understand the } \\
\text { utilization of palliative care } \\
\text { consultative services and } \\
\text { to identify specific factors } \\
\text { that might influence } \\
\text { physicians referral } \\
\text { practice. }\end{array}$ & $\begin{array}{l}74 \text { physicians, } 50 \\
\text { who had referred to } \\
\text { SPC, } 24 \text { who had } \\
\text { not referred. }\end{array}$ & $\begin{array}{l}\text { Interviews \& 11- } \\
\text { item, Likert scale } \\
\text { survey, } \\
\text { Univariate } \\
\text { statistics, } \\
\text { interviews } \\
\text { analyzed using a } \\
\text { standard } \\
\text { method. }\end{array}$ & $\begin{array}{l}\text { Physician, } \\
\text { nurse } \\
\text { practitioner, } \\
\text { social worker. }\end{array}$ & $\begin{array}{l}\text { Model of Care; } \\
\text { Professional Onus; } \\
\text { Expertise \& Trust; } \\
\text { Specialist Palliative } \\
\text { Care Operations }\end{array}$ & $\begin{array}{l}\text { Integrated care viewed positively. Majority want to maintain } \\
\text { relationship and role with patient. Some want to turn over care } \\
\text { to specialists at end of life. Specialists seen as experts for } \\
\text { advanced disease symptom management. }\end{array}$ \\
\hline $\begin{array}{l}\text { Ward et al. } \\
\text { (2009) } \\
\text { Australia, } 33\end{array}$ & $\begin{array}{l}\text { To investigate the attitudes } \\
\text { of oncologists and trainees } \\
\text { toward SPC and } \\
\text { collaboration with SPC } \\
\text { services }\end{array}$ & $\begin{array}{l}115 \text { total, } 78 \\
\text { oncologists, } \\
37 \text { trainees. }\end{array}$ & $\begin{array}{l}\text { Web survey, } \\
\text { Likert \& open- } \\
\text { ended questions, } \\
\text { Descriptive } \\
\text { statistics, } \\
\text { thematic } \\
\text { analysis. }\end{array}$ & Not described. & $\begin{array}{l}\text { Model of Care; } \\
\text { Expertise \& Trust; } \\
\text { Skill Building vs. } \\
\text { Deskilling; } \\
\text { Specialist Palliative } \\
\text { Care Operations }\end{array}$ & $\begin{array}{l}\text { Frequent integration of specialist services, although frequency } \\
\text { could increase. Some role confusion. Good communication } \\
\text { helps to mitigate role confusion. Desire for even more } \\
\text { integration. Greater disease specific expertise desired for } \\
\text { specialists. }\end{array}$ \\
\hline $\begin{array}{l}\text { Le and Watt } \\
(2010) \\
\text { Australia, } 31\end{array}$ & $\begin{array}{l}\text { To assess the care } \\
\text { provided to patients dying } \\
\text { within the hospital and } \\
\text { understand senior } \\
\text { clinicians decision making } \\
\text { around referral to SPC. }\end{array}$ & $\begin{array}{l}27 \text { clinicians: } 10 \\
\text { Nurses, } 11 \\
\text { physicians, } 2 \text { social } \\
\text { workers, } 2 \text { pastoral } \\
\text { care, } 1 \text { speech } \\
\text { pathologist, } 1 \text { OT }\end{array}$ & $\begin{array}{l}\text { Retrospective } \\
\text { chart review, } \\
\text { semi-structured } \\
\text { interviews, } \\
\text { thematic } \\
\text { analysis. }\end{array}$ & Not described. & $\begin{array}{l}\text { Model of Care; } \\
\text { Professional Onus; } \\
\text { Expertise \& Trust; } \\
\text { Specialist Palliative } \\
\text { Care Operations }\end{array}$ & $\begin{array}{l}\text { Integrated care viewed as valuable but not accessed as } \\
\text { frequently as it could be. Timing of involvement unclear. } \\
\text { Expertise of specialists appreciated. Some role confusion can } \\
\text { occur, desire to retain involvement in patient's care, maintain } \\
\text { skills. }\end{array}$ \\
\hline $\begin{array}{l}\text { Sasahara et } \\
\text { al. (2010) } \\
\text { Japan, } 31\end{array}$ & $\begin{array}{l}\text { To clarify the activities, } \\
\text { patient outcome, and } \\
\text { referring staff's view of an } \\
\text { established SPC } \\
\text { Consultation Team in } \\
\text { Japan }\end{array}$ & 68 nurses & $\begin{array}{l}\text { Survey, Likert } \\
\text { scale, yes/no \& } \\
\text { open-ended } \\
\text { questions, } \\
\text { Descriptive } \\
\text { statistics, } \\
\text { thematic } \\
\text { analysis. }\end{array}$ & $\begin{array}{l}\text { Physician, } \\
\text { certified nurse } \\
\text { specialists and } \\
\text { psychiatrist. }\end{array}$ & $\begin{array}{l}\text { Expertise \& Trust; } \\
\text { Skill Building vs. } \\
\text { Deskilling; } \\
\text { Specialist Palliative } \\
\text { Care Operations }\end{array}$ & $\begin{array}{l}\text { Expertise, inclusion of ward staff, and responsiveness of } \\
\text { specialists facilitate integration. }\end{array}$ \\
\hline $\begin{array}{l}\text { Norton et al. } \\
\text { (2011) } \\
\text { USA, } 31\end{array}$ & $\begin{array}{l}\text { To describe the multiple } \\
\text { perspectives of } \\
\text { administrators and } \\
\text { clinicians about the } \\
\text { tensions between a SPC } \\
\text { and the larger hospital } \\
\text { setting. }\end{array}$ & $\begin{array}{l}79 \text { participants total, } \\
21 \text { hospital } \\
\text { leadership, } 33 \\
\text { clinicians who used } \\
\text { SPC, and } 25 \text { from } \\
\text { SPC team }\end{array}$ & $\begin{array}{l}\text { Ethnographic } \\
\text { study, in-depth } \\
\text { interviews, and } \\
\text { "cultural } \\
\text { artifacts". } \\
\text { Analysis not } \\
\text { described. }\end{array}$ & $\begin{array}{l}\text { Physicians, } \\
\text { nurse } \\
\text { practitioners, } \\
\text { social worker, } \\
\text { chaplain, } \\
\text { psychologist, } \\
\text { ethicist, } \\
\text { massage } \\
\text { therapist, } \\
\text { bereave. } \\
\text { coordinator, } \\
\text { and a harpist. }\end{array}$ & $\begin{array}{l}\text { Model of Care; } \\
\text { Professional Onus; } \\
\text { Expertise \& Trust; } \\
\text { Specialist Palliative } \\
\text { Care Operations }\end{array}$ & $\begin{array}{l}\text { Mix of integrated and linear care. Greater utilisation of } \\
\text { specialist services led to even higher rates of integration. } \\
\text { Desire for mutual respect of expertise. Easy access to } \\
\text { specialist services facilitated integration. Concerns about role } \\
\text { confusion and meaning of referral on professional identify } \\
\text { cited as barriers to integrating care. }\end{array}$ \\
\hline
\end{tabular}


Table 3: Data Extraction and Study Quality

\begin{tabular}{|c|c|c|c|c|c|c|}
\hline $\begin{array}{l}\text { Author (Year) } \\
\text { Cntry, Score }\end{array}$ & Research Question & Participants & Method & $\begin{array}{l}\text { Pall Care } \\
\text { Team } \\
\end{array}$ & Themes & Key Findings \\
\hline $\begin{array}{l}\text { Burton and } \\
\text { Payne (2012) } \\
\text { England, } 32\end{array}$ & $\begin{array}{l}\text { To produce explanatory } \\
\text { practice model to help } \\
\text { clinicians meet the } \\
\text { palliative and end of life } \\
\text { care needs of patients and } \\
\text { families through the } \\
\text { integration of palliative } \\
\text { care within acute stroke } \\
\text { services. }\end{array}$ & $\begin{array}{l}29 \text { total: } 1 \\
\text { psychologist, } 1 \\
\text { physician, } 1 \text { health } \\
\text { care assist, } 2 \text { OT, } 2 \\
\text { PT, } 5 \text { specialist } \\
\text { stroke nurses, } 1 \\
\text { speech language } \\
\text { pathology, } 7 \text { stroke } \\
\text { unit nursing, } 1 \text { family } \\
\text { advocacy, } 8 \text { not } \\
\text { identified. }\end{array}$ & $\begin{array}{l}\text { Semi-structured } \\
\text { interviews. } \\
\text { Thematic } \\
\text { analysis. }\end{array}$ & Not described. & $\begin{array}{l}\text { Model of Care; } \\
\text { Professional Onus; } \\
\text { Expertise \& Trust; } \\
\text { Specialist Palliative } \\
\text { Care Operations }\end{array}$ & $\begin{array}{l}\text { Linear care common. Involvement of specialist services seen } \\
\text { as failure. Involvement of specialist occurring only when ward } \\
\text { team has done all they can think of to treat. Concern } \\
\text { specialists do not have enough expertise to manage stroke } \\
\text { patients. }\end{array}$ \\
\hline $\begin{array}{l}\text { Gott et al. } \\
(2012) \\
\text { England and } \\
\text { New Zealand, } \\
33\end{array}$ & $\begin{array}{l}\text { To explore understandings } \\
\text { of, and perceived roles in } \\
\text { relation to, palliative care } \\
\text { provision amongst } \\
\text { generalist and specialist } \\
\text { heath providers in England } \\
\text { and New Zealand }\end{array}$ & $\begin{array}{l}\text { England }-58,5 \text { of } \\
\text { who worked in acute } \\
\text { hospital } \\
\mathrm{NZ}-80,10 \text { of who } \\
\text { worked in acute } \\
\text { hospital. Mix of } \\
\text { professions. }\end{array}$ & $\begin{array}{l}\text { Focus groups. } \\
\text { Analyzed with } \\
\text { grounded theory. }\end{array}$ & Not described. & $\begin{array}{l}\text { Model of Care; } \\
\text { Professional Onus; } \\
\text { Expertise \& Trust; } \\
\text { Skill Building vs. } \\
\text { Deskilling; } \\
\text { Specialist Palliative } \\
\text { Care Operations }\end{array}$ & $\begin{array}{l}\text { Linear care. Integration hampered by role confusion. } \\
\text { Specialisation of services seen as fragmenting care and taking } \\
\text { responsibility and skills from generalists. All generalists should } \\
\text { be able to provide palliative care. }\end{array}$ \\
\hline $\begin{array}{l}\text { Johnson et al. } \\
\text { (2012) } \\
\text { England, } 28\end{array}$ & $\begin{array}{l}\text { To survey Heart Failure } \\
\text { Nurse Specialists about } \\
\text { their attitudes regarding } \\
\text { general PC provision for } \\
\text { HF and access to SPC. }\end{array}$ & $\begin{array}{l}152 \text { nurses in } 2005 . \\
174 \text { nurses in } 2010 .\end{array}$ & $\begin{array}{l}\text { Wed-based and } \\
\text { paper surveys. } \\
\text { Analysis not } \\
\text { discussed. }\end{array}$ & Not described. & $\begin{array}{l}\text { Model of Care; } \\
\text { Expertise \& Trust; } \\
\text { Specialist Palliative } \\
\text { Care Operations }\end{array}$ & $\begin{array}{l}\text { Integrated care valued but not actualized. Ease of access } \\
\text { important for facilitating integration. Concern that specialists } \\
\text { might lack expertise to manage heart failure. }\end{array}$ \\
\hline $\begin{array}{l}\text { Armstrong et } \\
\text { al. (2013) } \\
\text { USA, } 29\end{array}$ & $\begin{array}{l}\text { To measure the impact of } \\
\text { SPC Consultation on } \\
\text { clinical, customer, } \\
\text { operational, and financial } \\
\text { domains. }\end{array}$ & $\begin{array}{l}18 / 19 \text { participants } \\
\text { responded. } \\
\text { Physicians and other } \\
\text { providers }\end{array}$ & $\begin{array}{l}\text { Survey, } 9 \text { item } \\
\text { Likert scale. } \\
\text { Descriptive } \\
\text { statistics. }\end{array}$ & Not described. & $\begin{array}{l}\text { Model of Care; } \\
\text { Specialist Palliative } \\
\text { Care Operations }\end{array}$ & $\begin{array}{l}\text { Integration is desired and positive experience. Communication } \\
\text { and ease of access make integration possible. }\end{array}$ \\
\hline $\begin{array}{l}\text { (Lane et al., } \\
\text { 2014), } \\
\text { Australia, } 30\end{array}$ & $\begin{array}{l}\text { To explore health care } \\
\text { professionals' views and } \\
\text { experiences of } \\
\text { interdisciplinary } \\
\text { interactions when caring } \\
\text { for patients with advanced } \\
\text { cancer who present to the } \\
\text { emergency room. }\end{array}$ & $\begin{array}{l}83 \text { professionals in } \\
\text { focus groups, } 11 \\
\text { one-on-one } \\
\text { interviews. }\end{array}$ & $\begin{array}{l}\text { Focus groups, } \\
\text { Semi structured } \\
\text { phone } \\
\text { interviews. } \\
\text { Analyzed using } \\
\text { thematic } \\
\text { analysis. }\end{array}$ & Not described. & $\begin{array}{l}\text { Model of Care; } \\
\text { Professional Onus; } \\
\text { Expertise \& Trust; } \\
\text { Specialist Palliative } \\
\text { Care Operations }\end{array}$ & $\begin{array}{l}\text { Integrated care desired but not actualized. Communication } \\
\text { and access would improve integration. Lack of trust in other's } \\
\text { expertise a barrier to integration. }\end{array}$ \\
\hline
\end{tabular}




\section{Appendix A: Database Searches}

PsycINFO: $(((((((((D E$ "Professional Consultation") OR (DE "Social Workers")) OR (DE "Medical Personnel")) OR (DE "Interdisciplinary Treatment Approach")) OR (DE "Professional Specialization")) OR (DE "Attitudes")) OR (DE "Perception")) OR (DE "Communication")) OR (DE "Decision Making")) OR (DE "Roles")) OR (DE "Teams") AND ((DE "Palliative Care") OR (DE "Terminally III Patients")) OR (DE "Hospice") Limiters Published Date: 19900101-20141231 = 1537 articles

PubMed: ((((((("Patient Care Team"[Mesh]) OR "Consultants"[Mesh]) OR "Medical Staff, Hospital"[Mesh]) OR "Social Work"[Mesh]) OR "Nursing Staff, Hospital"[Mesh]) OR "Allied Health Personnel"[Mesh])) AND (((("Interprofessional Relations"[Mesh]) OR "Attitude of Health Personnel"[Mesh]) OR "Interdisciplinary Communication"[Mesh]) OR "Cooperative Behavior"[Mesh])) AND ((("Hospice Care"[Mesh]) OR "Terminal Care"[Mesh]) OR "Palliative Care"[Mesh])) AND ("1990/01/01"[Date - Publication] : "2014/12/31"[Date - Publication]) = 1221 articles

Web of Science: ("palliative care" OR "terminal care" or "end of life" or "hospice") AND ("professional consultation" OR cooperat* OR collaborat* OR "interdisciplinary team*" OR interprofessional OR attitude* OR perception*) AND (social work* OR medical team OR allied health OR physician* OR doctor* OR nurse*) Timespan=1990-2014 = 2686

CINAHL: (MH "Palliative Care") OR (MH "Hospice Care") OR (MH "Terminal Care") AND (MH "Medical Staff, Hospital") OR (MH "Multidisciplinary Care Team") AND (MH "Joint Practice") OR (MH "Interprofessional Relations") OR (MH "Intraprofessional Relations") OR (MH "Consultants") OR (MH "Referral and Consultation") OR (MH "Attitude of Health Personnel") OR (MH "Communication") Limiters - Published Date: 19900101-20141231 = 2381

Social Services Abstracts (ProQuest): (SU.EXACT("Palliative Care") OR SU.EXACT("Terminal Care") OR SU.EXACT("Hospices")) AND (SU.EXACT("Professional Consultation") OR SU.EXACT("Cooperation") OR SU.EXACT("Interdisciplinary Approach") OR SU.EXACT("Perceptions") OR SU.EXACT("Attitudes")) AND (SU.EXACT("Health Professions") OR SU.EXACT("Paramedical Personnel") OR SU.EXACT("Physicians") OR SU.EXACT("Social Work") OR SU.EXACT("Nurses")) between 1990 and $2014=5$

Individual Journal Search Terms: (("palliative care" OR "terminal care" OR "end of life" OR hospice) AND ("professional consultation" OR consultat* OR cooperat* OR collaborat*) AND ("interdisciplinary team" OR inter-professional OR "medical team" OR "social work") AND (attitudes OR perceptions)) 